Supporting Information:

\title{
Binding Modes of Cucurbit[6]uril and Cucurbit[7]uril with a Tetracationic Bis(viologen) Guest
}

Lina Yuan, Ruibing Wang and Donal H. Macartney*

Department of Chemistry, Queen's University, Kingston, ON K7L 3N6 Canada

Contents:

Figure S1. ${ }^{1} \mathrm{H}$ NMR spectrum of $\left[\mathrm{CH}_{3} \mathrm{bpy}\left(\mathrm{CH}_{2}\right)_{6} \mathrm{bpyCH}_{3}\right]^{4+}$ in DMSO-d $\mathrm{d}_{6} . \quad$ S2

Figure S2. ${ }^{13} \mathrm{C}$ NMR spectrum of $\left[\mathrm{CH}_{3}\right.$ bpy $\left.\left(\mathrm{CH}_{2}\right)_{6} \mathrm{bpyCH}_{3}\right]{ }^{4+}$ in DMSO- $\mathrm{d}_{6} . \quad$ S2

Calculations of Stability Constants $\quad$ S3

$\begin{array}{ll}\text { Reference } & \text { S4 }\end{array}$ 


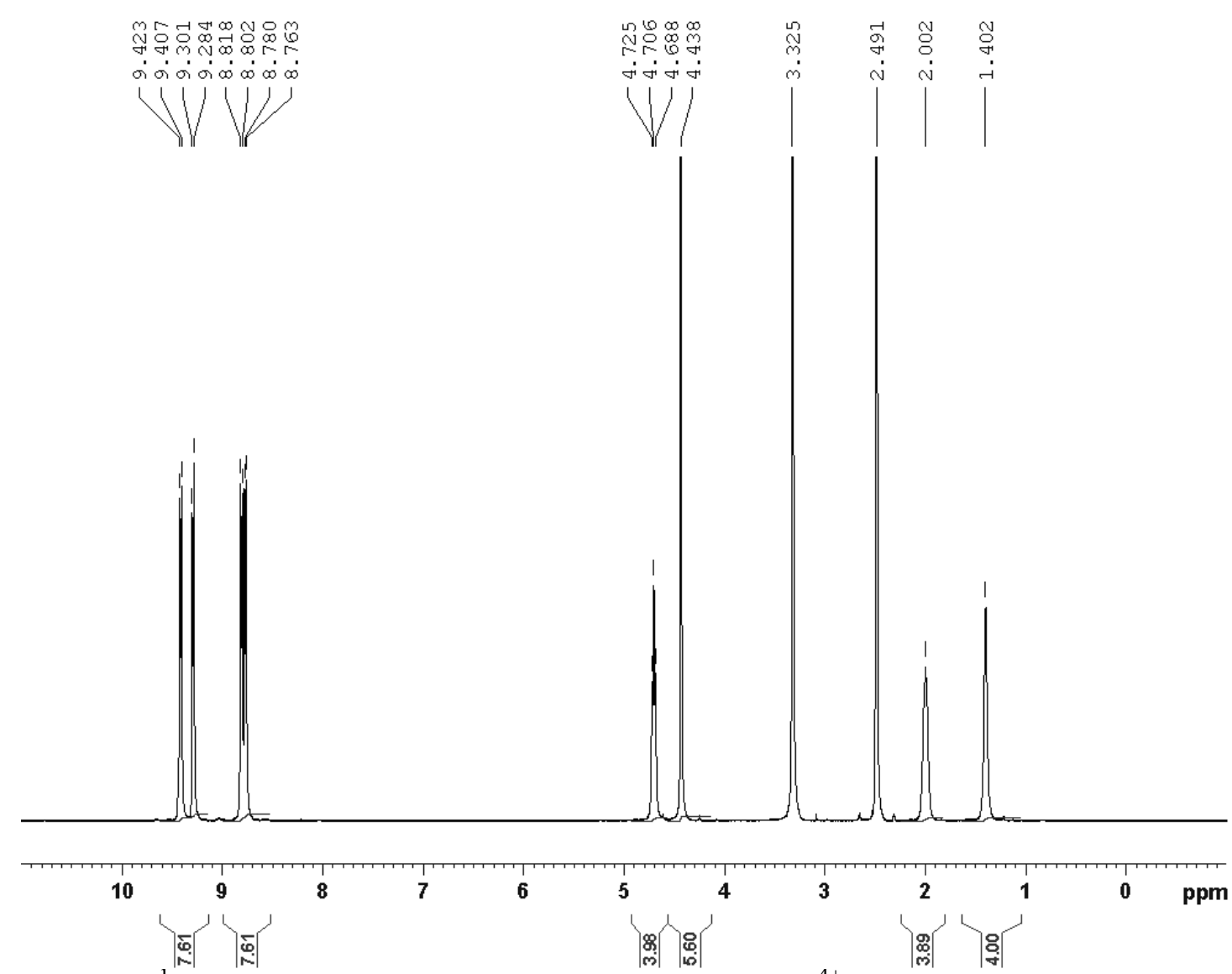

Figure S1. ${ }^{1} \mathrm{H}$ NMR Spectrum of $\left[\mathrm{CH}_{3} \mathrm{bpy}\left(\mathrm{CH}_{2}\right)_{6} \mathrm{bpyCH}_{3}\right]^{4+}$ in DMSO-d $\mathrm{d}_{6}$.

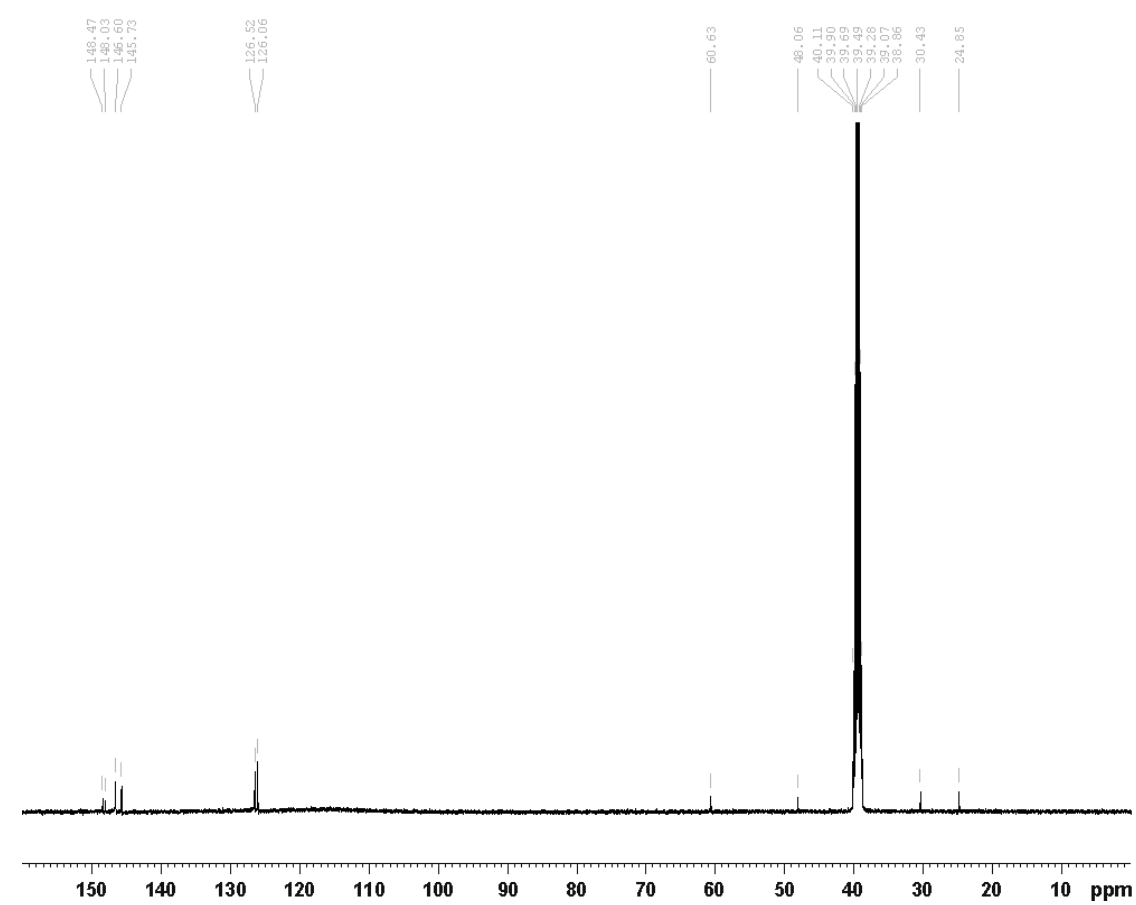

Figure S2. ${ }^{13} \mathrm{C}$ NMR spectrum of $\left[\mathrm{CH}_{3} \text { bpy }\left(\mathrm{CH}_{2}\right)_{6} \mathrm{bpyCH}_{3}\right]^{4+}$ in DMSO-d $\mathrm{d}_{6}$. 


\section{Calculations of Stability Constants}

The stability constants for the inclusion of $\left[\mathrm{CH}_{3} \mathrm{bpy}\left(\mathrm{CH}_{2}\right)_{6} \mathrm{bpyCH}_{3}\right]^{4+}$ by $\mathrm{CB}[6]$ and $\mathrm{CB}[7]$ was determined by ${ }^{1} \mathrm{H}$ NMR titrations, using integrations of the host and free and bound guest proton resonances (slow exchange of the guest on the NMR timescale) to determine the guest species concentrations in solution. The value of $K_{\mathrm{CB}[\mathrm{n}]}$ was determined from:

$K_{\mathrm{CB}[\mathrm{n}]}=\frac{\left[\{\mathrm{L} \cdot \mathrm{CB}[\mathrm{n}]\}^{4+}\right]}{\left[\mathrm{L}^{4+}\right]_{\text {free }}[\mathrm{CB}[\mathrm{n}]]_{\text {free }}}$

where $[\mathrm{CB}[\mathrm{n}]]_{\text {free }}=[\mathrm{CB}[\mathrm{n}]]_{\text {total }}-\left[\{\mathrm{L} \cdot \mathrm{CB}[\mathrm{n}]\}^{4+}\right]$. The reported equilibrium constants are an average of values determined at four $\mathrm{CB}[\mathrm{n}]$ concentrations. The spectrum below shows the peaks used to determine the free $(\bullet)$ and bound $(\circ)$ guest concentrations and the total $\mathrm{CB}[6]$ concentration $(\boldsymbol{\Delta})$ for the $\mathrm{CB}[6]$ stability constant calculations.

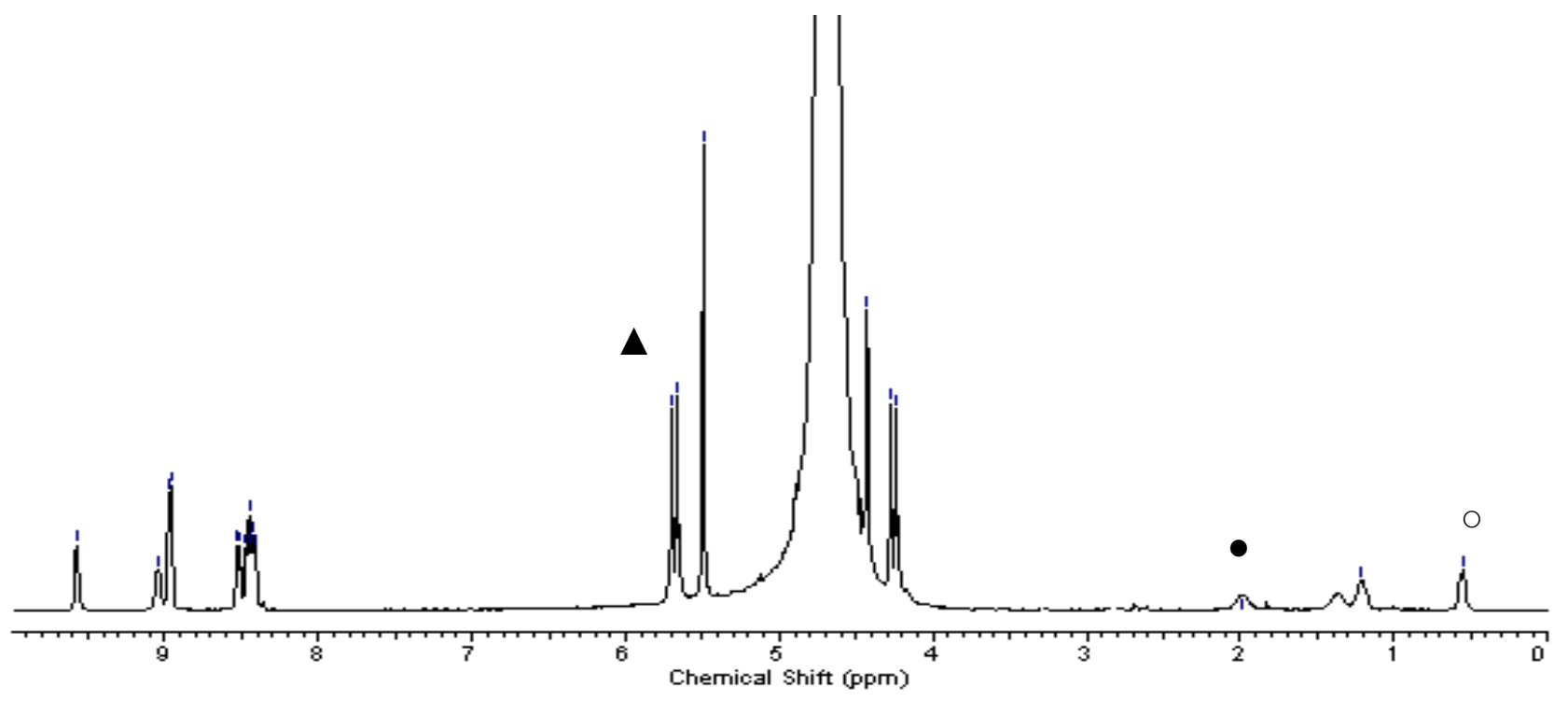


The stability constant for the binding of the second $\mathrm{CB}[7]$ to $\left[\mathrm{CH}_{3} \text { bpy }\left(\mathrm{CH}_{2}\right)_{6} \mathrm{bpyCH}\right]^{4+} \quad\left(\mathrm{L}^{4+}\right)$ to form $\left[\mathrm{CH}_{3} \text { bpy }\left(\mathrm{CH}_{2}\right)_{6} \mathrm{bpyCH}_{3} \cdot 2 \alpha-\mathrm{CD}\right]^{4+}$ was determined using the equation below, ${ }^{1}$

$[\mathrm{CD}]_{\mathrm{t}} / \Delta \delta_{\mathrm{obs}}=\left([\mathrm{CD}]_{\mathrm{t}}-\left[\mathrm{L}^{4+}\right]_{\mathrm{t}}-\left[\mathrm{L} \cdot 2 \mathrm{CD}^{4+}\right]\right) / \Delta \delta_{\mathrm{lim}}+1 /\left(\Delta \delta_{\mathrm{lim}} K_{2 \mathrm{CD}}\right)$

where $\left[\mathrm{L} \cdot 2 \mathrm{CD}^{4+}\right]=\left[\mathrm{L}^{4+}\right]_{\mathrm{t}}\left(\Delta \delta_{\mathrm{obs}} / \Delta \delta_{\mathrm{lim}}\right)$ and $[\mathrm{CD}]=[\mathrm{CD}]_{\mathrm{t}}-\left[\mathrm{L} \cdot 2 \mathrm{CD}^{4+}\right]$. By plotting $[C D]_{\mathrm{t}} / \Delta \delta_{\text {obs }}$ against $[\mathrm{CD}]_{\mathrm{t}}-\left[\mathrm{L}^{4+}\right]_{\mathrm{t}}-\left[\mathrm{L} \cdot 2 \mathrm{CD}^{4+}\right]$, the ratio of the slope to the intercept gives the value of $K_{2 \mathrm{CD}}$.

\section{Reference}

1. Connors, K. A. Binding Constants. The Measurement of Molecular Complex Stability; John Wiley \& Sons: New York, 1987, p. 197. 